
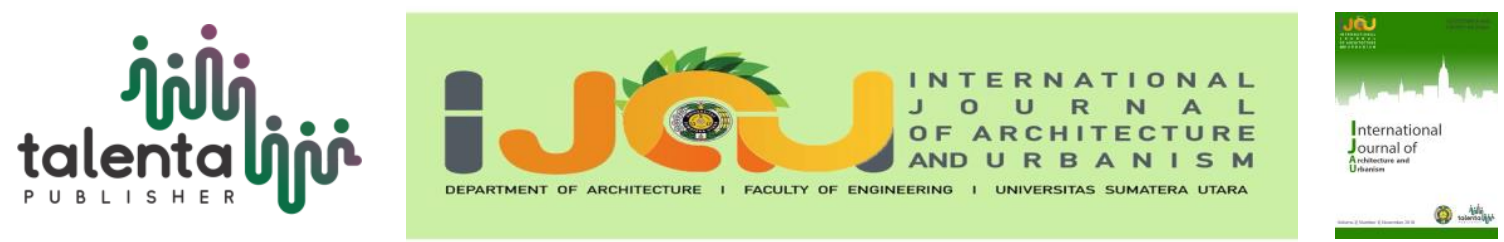

\title{
Application of Tropical Architecture in Convention Hall Design
}

\author{
Harisdani, D.D..$^{1 *}$, Kartika, $F^{1}$ \\ ${ }^{1}$ Architecture Department, Faculty of Engineering, Universitas Sumatera Utara, Medan, Indonesia
}

\begin{abstract}
Meeting as one of the daily activities become a base to provide a space which can accommodate communities activities, especially Medan, Indonesia. However, as the number of population increase, especially in the areas with the light of convention hall building, the design of convention hall is required. Building developments that occur at this time in the suburbs of Medan become the basis to create a convention hall. Respond to this problem, a convention hall designed to consider local wisdom in the urban area by applying elements of tropical architecture.
\end{abstract}

Keyword: architecture, tropical architecture, local wisdom, convention hall

\section{Introduction}

The meeting is a world culture that's related to an incentive, exhibition, and convention. Some part of the conference are seminars, wedding receptions, etc. It is the based on creating a space that accommodates it.

In urban areas which the areas that have the accretion of rapid occupation with the potential of wides areas of land need to at least establish one Convention Hall. It is because the public space needs are highly significantly related to the building development in the city as in Medan. The establishment of Kualanamu International Airport in Deli Serdang, Medan, Indonesia is the beginning of the increase of infrastructure development in that urban. It also becomes the main reason to establish the convention hall which is necessary and needed in residential areas.

Related to the local wisdom is currently discusses in various seminars and several public lectures, buildings in Indonesia should apply one of the locality in the region. It triggers traditional architecture, vernacular architecture, and even tropical architecture often apply to buildings today.

*Corresponding author at:Departement of Architecture, Faculty of Engineering, Universitas Sumatera Utara,

Jalan Perpustakaan Gedung J07, Medan 20155, Indonesia

E-mail address: devin.defriza@usu.ac.id 


\section{Literature Review}

\section{Function and Architectural Theory}

Convention means as a meeting room for some people to changes mind and opinion about getting aim from community problems [1]. Convention hall firstly traced in the middle 19th century in England. Generally known as exhibition hall and space designed to bring together communities to discuss the common interest of a subject [2]. Based on the theory of the image of the city which states the city elements divided into five, namely paths, edges, districts, nodes, and landmarks which interrelated [3]. However, the public space such as the convention hall which included into that elements specifically nodes or landmarks. Landmarks and nodes have a similar means. The difference between both of them are the activities. Nodes have routine activities while landmarks nor enter because of can saw from the outside. Crossroads is part of nodes because of the function as navigation and more clearly seen if there is a public space.

In the development of cities, especially in the province of North Sumatra, covering the cities of Medan, Binjai, Deliserdang, and Karo (Mebidangro), Kuala Namu International Airport which acts as a landmark and nodes currently has a role as a transportation network that triggers development plans [4]. Planning must correspond with the local community needs. Differences in structural space and socio-cultural of the community become problems of urban planning in Indonesia [4]. It is the base to create the tropical convention hall because tropical is a local wisdom concept that very general use in several buildings in Indonesia.

The tropical convention hall is the architectural theme that the building concept adapts to tropical climates and tend to open also found in all tropical countries [5]. The tropical architecture concept is a building solution in the tropics. One characteristic of a region with a tropical climate is high rainfall therefore many buildings in tropical climates use sloping roofs with an average slope of $30^{\circ}-45^{\circ}$ to be able to drain rainwater well.

\section{Concept}

Thermal comfort is a feature of tropical architecture as a solution to prevent the sun's heat into the buildings. The step which easiest to get thermal comfort is using a mechanical air (using airconditioner). But, the cheapest is designing a building by considering the sun orientation, elements utilization, and building material, and landscape element [6]. The application of shading in a facade also can function as a heat retaining. Besides that, the sloping roof and cross ventilation is also the priority for the tropical building to flow the rainwater and air well (Figure $1)$. 


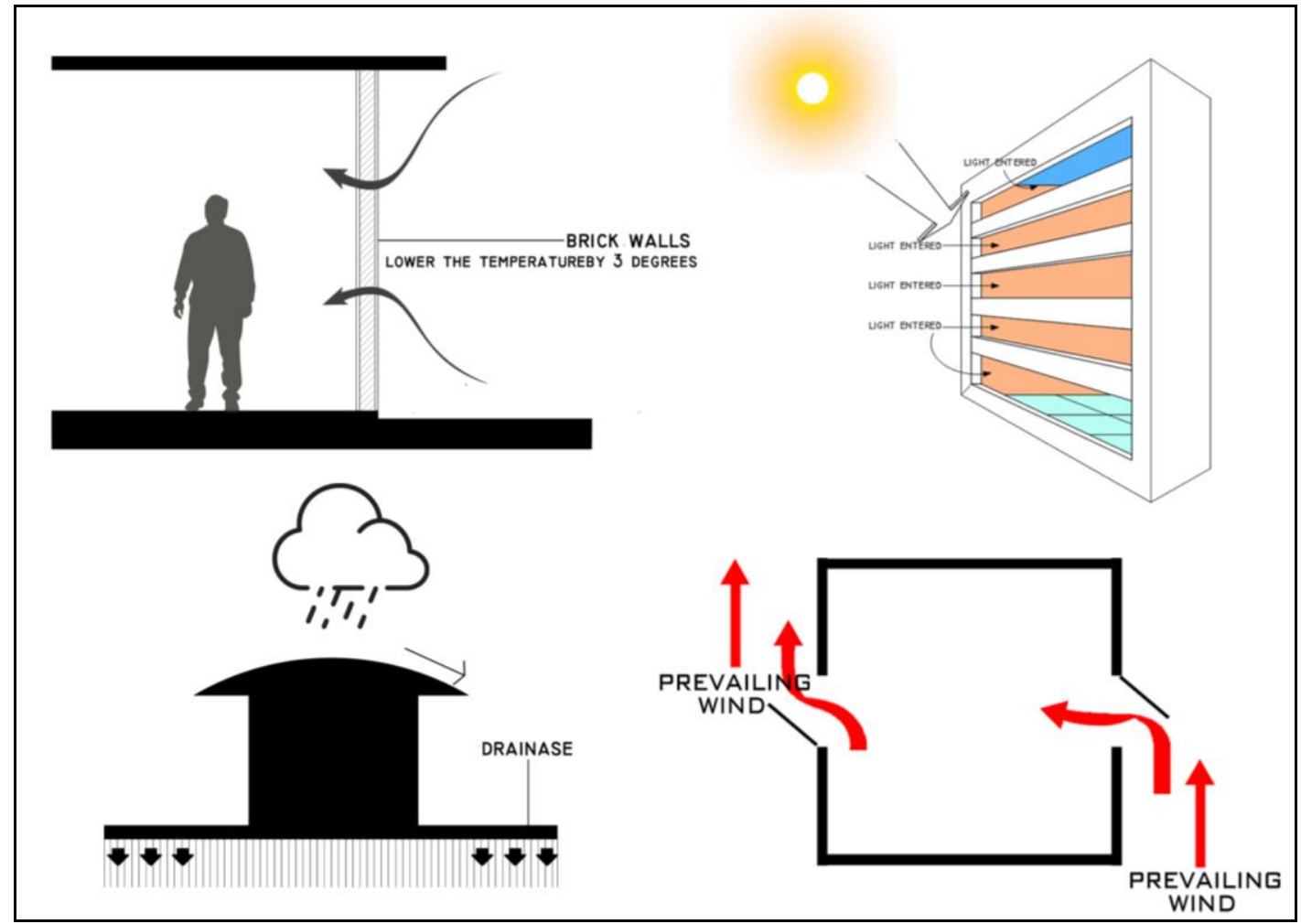

Figure 1. Tropical Architecture Concept

Public space such as a convention hall or performance hall which have a similar function visible from the building concept of Esplanade-Theatres on the Bay in Singapore which applying the modern tropical concepts. The building uses a mechanical air conditioning to create the thermal comfort such as stated above. All of the building faces consist of transparent glass and be perfect with the aluminum cladding (Figure 2). It responds to a solution of tropical architecture to reduce direct radiation of the sun into the building which can generate the greenhouse effect [7].

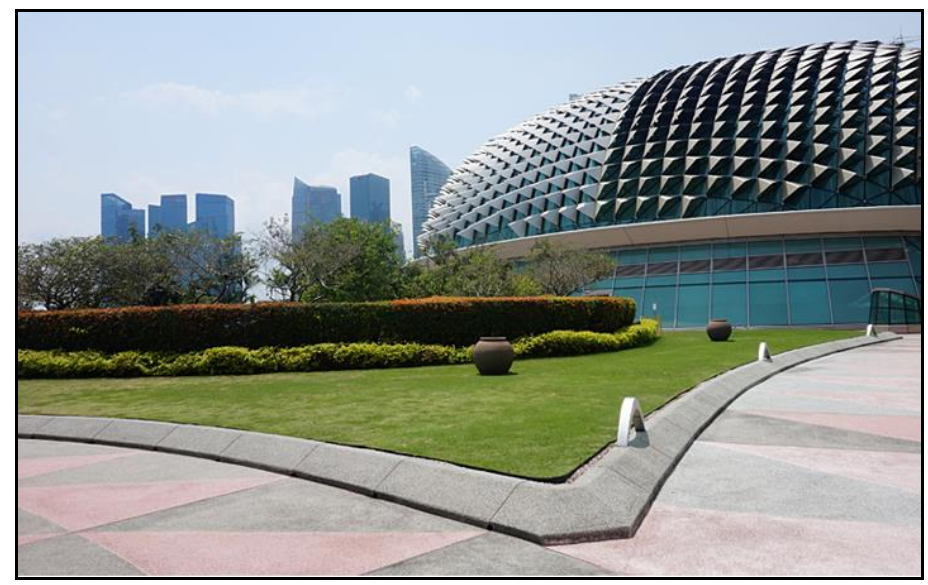

Figure 2. Esplanade-Theatres on the Bay Cladding Concept (Source: esplanade.com, Esplanade Tour, accessed on September 2018) 
Some ways to adopt the climate condition or the environment are from local wisdom. The geographical areas condition give the effect to building shapes which covering the aspect of architecture, construction, building material, and philosophy [8].

Space requirements at the convention hall are an auditorium, ballroom, meeting room, exhibition hall, food service, broadcasting, printing and translation, filming and publication, and others [1].

\section{Methodology}

The methodology of this project beginning with the selection of the project location by reviewing through of the city structure with the appropriate area especially in Medan, Indonesia. The project location selected by considering criteria of achievement. Specifically, the project located adjacent to the main road, smooth vehicle traffic, the wide road, hotel, and office. Besides that, the entry area must be easy to recognize and obvious to see [1].

Furthermore, the method of collecting data obtained through collecting literature studies and direct observation for getting data and know the object condition. Besides that, also do the comparative studies by searching data from the written source about a similar project. Concept approach is the next step after the methods of collecting data. It consists of data analysis which obtained from observational studies of the area and synthesis which the incorporation step from a data of fields sources and literature. A final step is a design approach which conclusion from the synthesis process which translated into a design in the form of design drawing.

\section{Result and Discussion}

\subsection{Exterior}

The elements of city architectural consist of eight elements namely, land use, intensity, building form and massing, open space, circulation and parking, pedestrian, signage, and conservation[9]. In the building design, the elements minimized. Then the zoning of outdoor space must have that element. Such as open space, circulation and parking, pedestrian, and signage.

The building problems in the primary artery are the high level of noise generated by the sound of vehicles on the road. Crossroad is also a traffic source. Therefore, a convention hall should be able to prevent it. The solution is giving the space between a building and road exceeds the minimum limit of the building boundary line which included in the element of land use (Figure $3)$. 


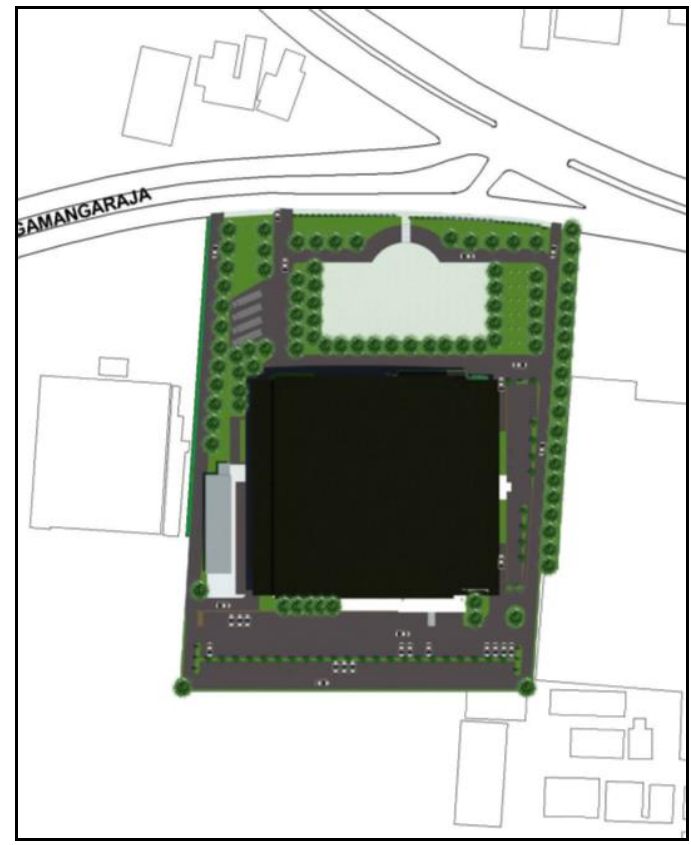

Figure 3. Representation of Siteplan Concept

Pavement elements in circulation, pedestrian, and open space elements such as asphalt and paving blocks make the ambient temperature around the building increase. Tree planting beside pavement is a solution of tropical architecture concept (Figure 4). Based on the results of Akbari and Parker's research, planting trees around the building serves to reduce the temperature entering the room by $3^{\circ} \mathrm{C}$.

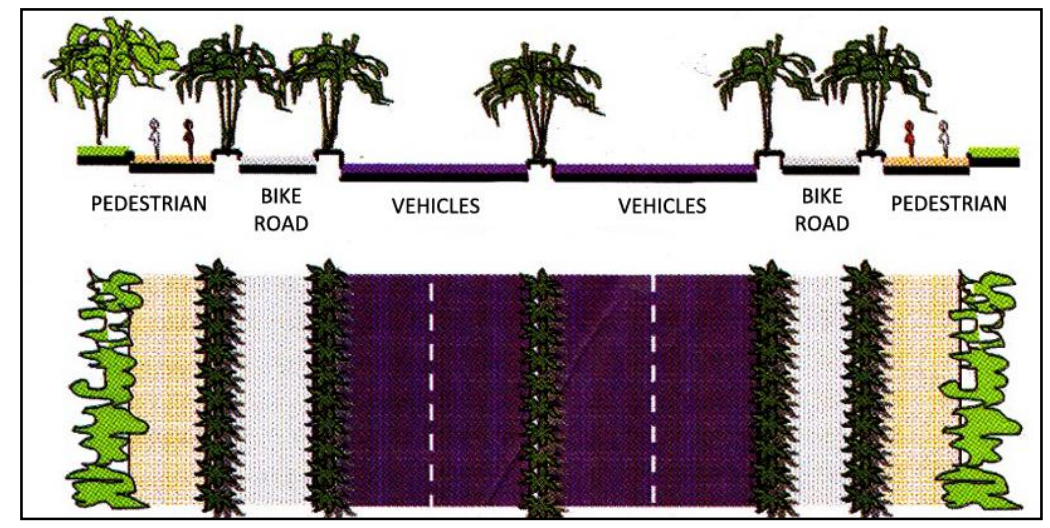

Figure 4. The Concept of Planting Trees Around The Road (Source: Karyono. T.H, 2016)

The elements of city architectural which transformed into a building visible at the ground plan. Outdoor space located at the front because of the function as a public space and a connector of outdoor and indoor space for pedestrians. Building's layout based on the concept of tropical architecture specifically the service area which located at western. It intends as a barrier to the 
sun's heat which produced in the afternoon so cannot be entered into the public and private room.

Therefore, in the service area so as not to overheat using a brick wall (Figure 5). The use of brick material can reduce the temperature by $3^{\circ} \mathrm{C}$ if the temperature difference between day and night is not less than $8^{\circ} \mathrm{C}$. It has studied by Cambridge Architectural Research Limited and is the concept of cooling down at night.

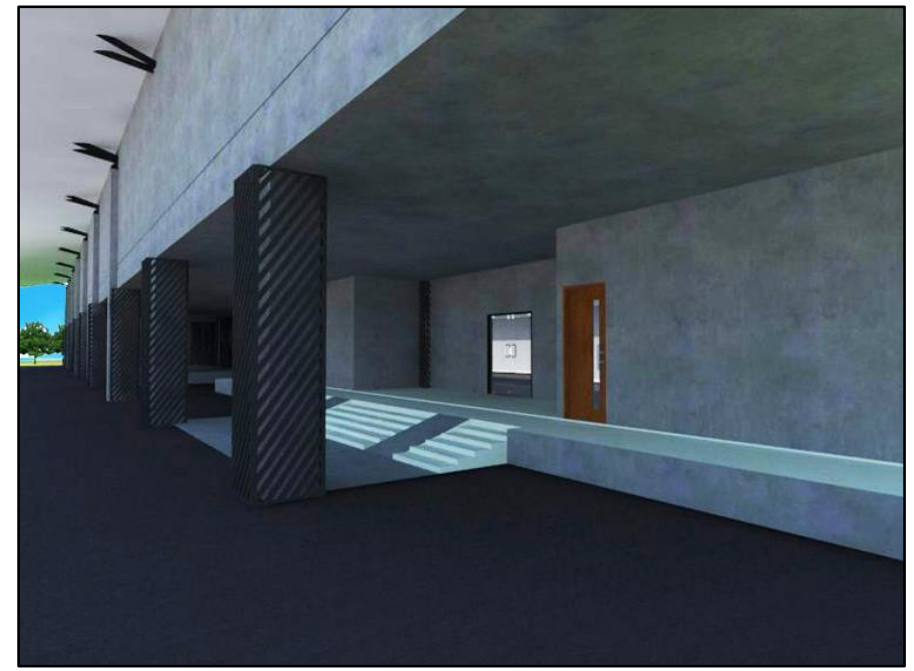

Figure 5. Visualization of West Entrance Model

\subsection{Building Form and Massing}

The shape of the building has designed by adopting basic shapes such as triangles, squares, and circles that transformed into extreme forms. The application of shading elements as a transformation of a prototype is also as a functional element to prevent the entry of sunlight into the building and use of aesthetic elements at buildings so not look stiff (Figure 6).

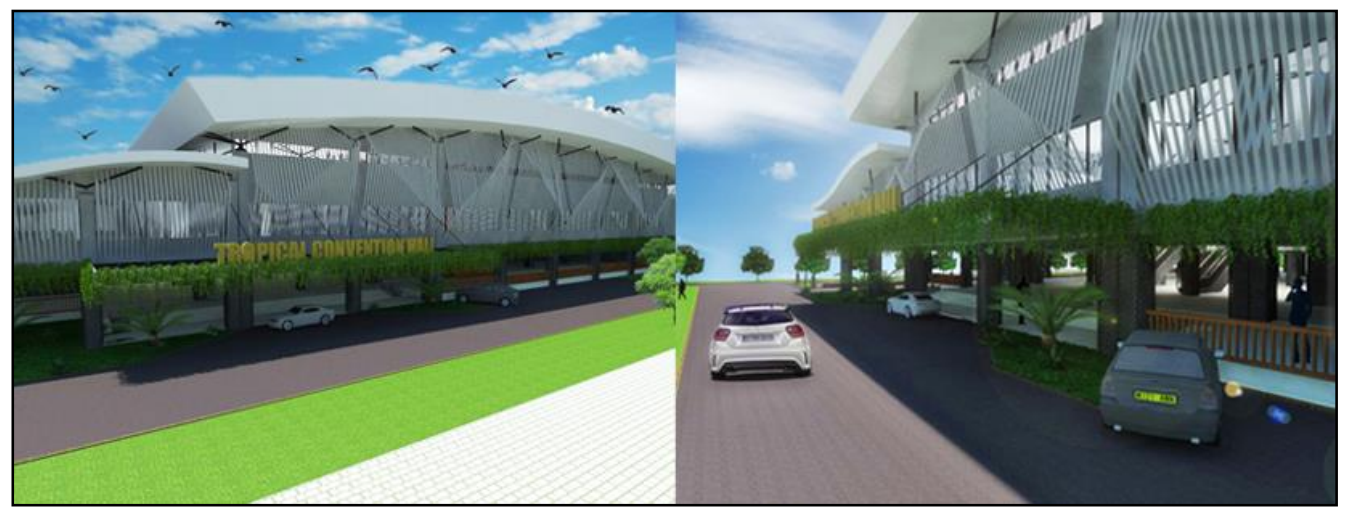

Figure 6. Visualization of Building Façade

Entrance building has marked with the words Tropical Convention Hall and vine arrangement. The building facade there is an abstract aluminum plate as a sun shading. Shading and vines in 
the facade beside its function as a heat buffer also serve to beautify the facade so as not to look stiff.

The arrangement of the aluminum plate as the shading on the facade creates a shadow attraction that beautifies the appearance of the inner space. Besides that the hollow plate arrangement functions so that air enters through the cavity of the plate towards the opening into the room and creates the cross ventilation concept (Figure 7).

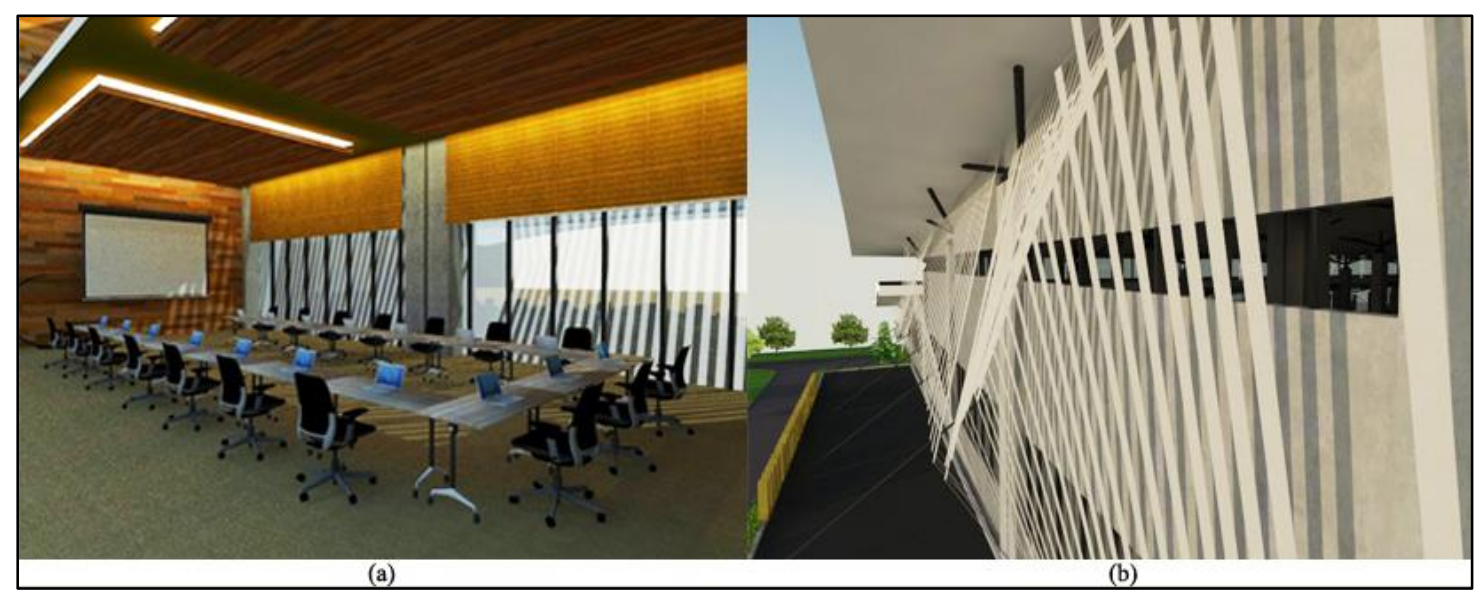

Figure 7. Visualization of Meeting Room (a), and Detail of Ventilation (b)

Openings element of tropical architecture can apply at the convention hall. It also is the concept of cross ventilation. The use of natural materials such as wood applied to buildings with the tropical architecture theme. Application of natural products that are not to preserve from the region itself is a local wisdom idea. The wooden lattice in the image below adds a tropical impression to the building with additional vines (Figure 8).

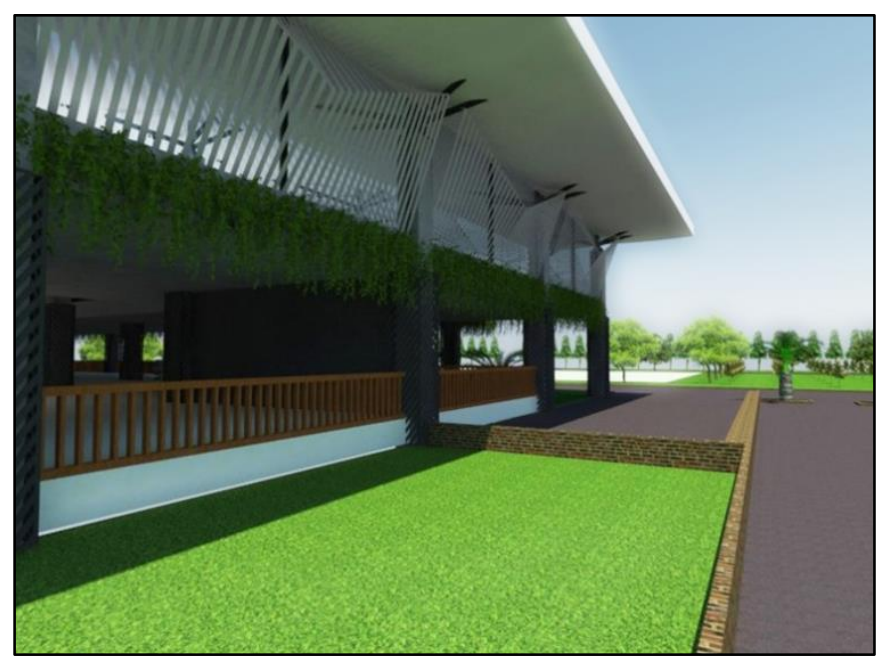

Figure 8. Visualization of Ventilation

\subsection{Interior}

Tropical buildings should consider the building orientation including the sun direction and wind direction. The building should direct to the north and south so, the roof at the east and west can 
be made lower [6] and apply the eavesdrops house so the heat radiation can be reflected. Space organizations for the tropics based on the theory of tropical architecture that main spaces such as public spaces and private spaces should avoid the west side (Figure 9 and 10) unless there is shadowing from other buildings or large trees. The western wall of the room gets high solar radiation then space inside is hot. So it should be placed service area in western [10].

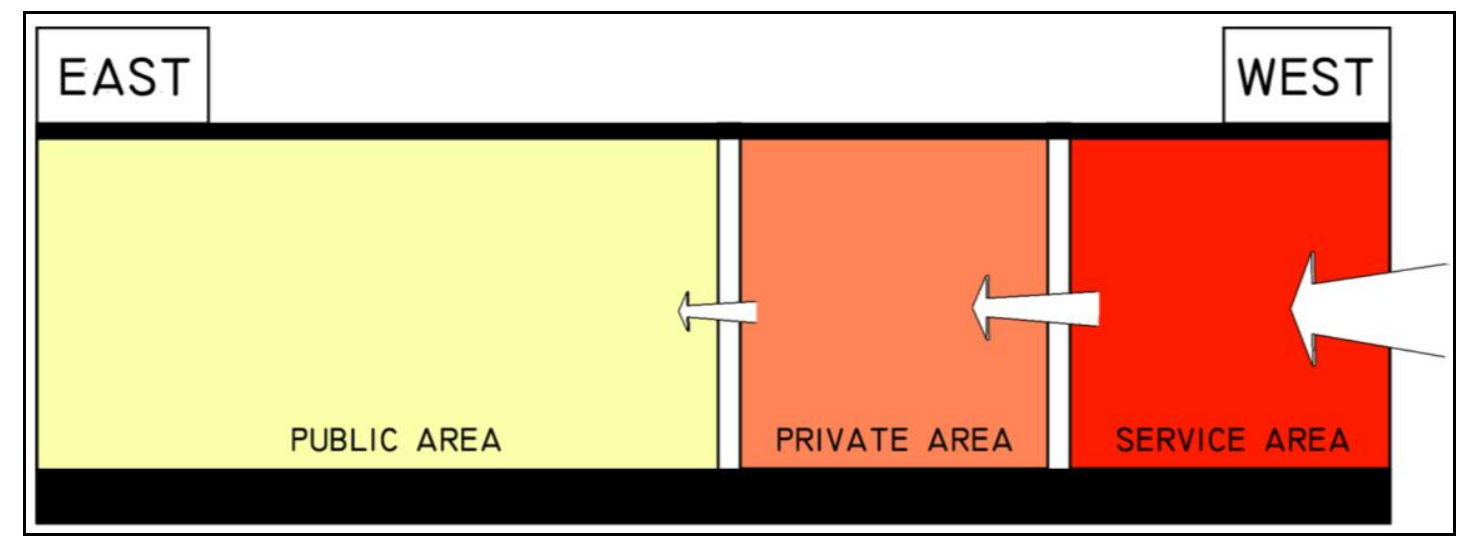

Figure 9. Zoning Concept by Tropical Architecture Theory

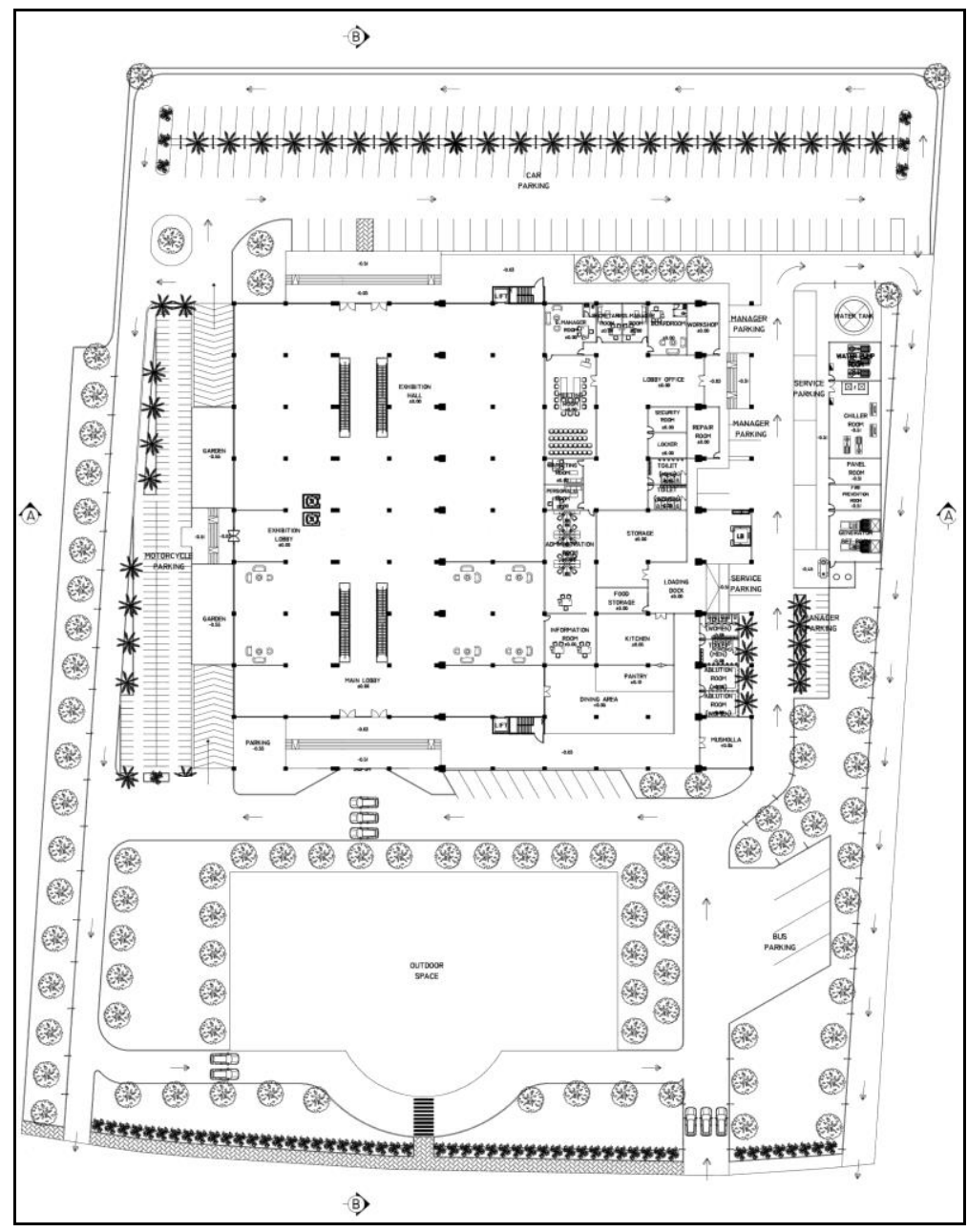

Figure 10. Representation of Groundplan 
Space relationships connected in several ways, namely space in space, interlocking space, adjacent spaces, and space connected by a shared room [11]. Viewed from zoning based on the theory of tropical architecture, then it can be said that space related to each other. The space division of an auditorium use a retractable wall which usually uses at the various buildings, but this step would be difficult applied to the performance hall which has a level difference. To get the flexibility, a folding chair use in the room has a flat floor. Storage for the folding chair provided, for 1000 folding chairs requires a storage area of 20-36 m2 [12]. The ceiling concept in the auditorium room has a sound delivery screen to avoid differences in sound volume by sounding concentration. Space with high ceilings and narrow walls that reflect diffusely have the best room acoustics (Figure 11)[13].

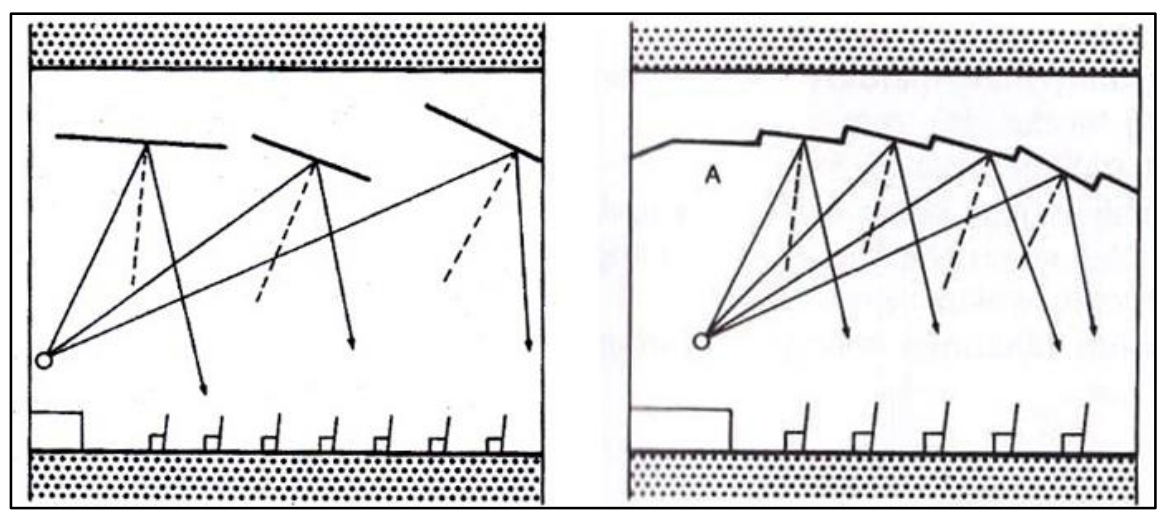

Figure 11. Acoustic Plafond Concept

\subsection{Structure and Utility}

\section{Structure}

If the building width reaches more than 30 meters, it must have a distance of the buildings (dilated). Dilated used at the connection of low and high buildings, main buildings and wing buildings, and very long buildings which cannot withstand deformation of a decrease in a foundation, earthquakes, and others that cause cracks. The type of dilatation which usually used namely dilated with two column which the distance between the column is at least 15 centimeters (Figure 12 and 13) [14].

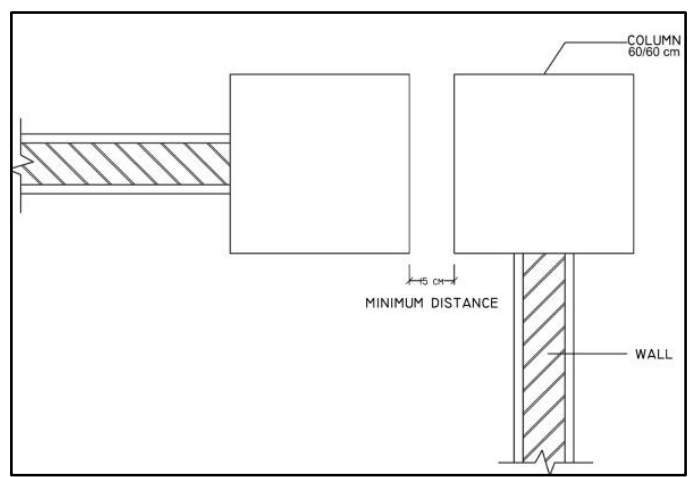

Figure 12. Dilated with 2 Columns 


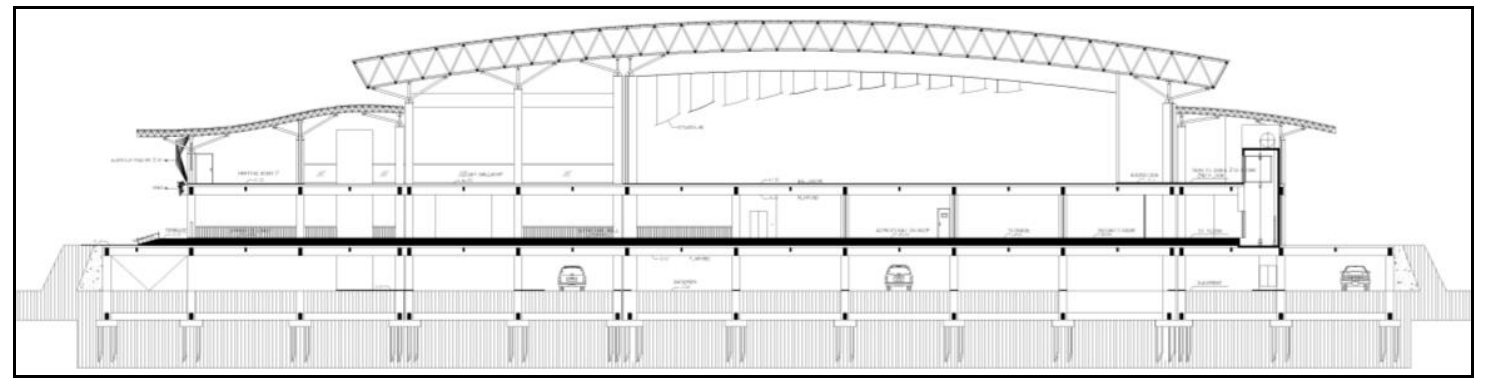

Figure 13. Representation ofBuilding Section

The curved shape of the building roof is a transformation process of a triangular roof that uses a space frame system (Figure 14). Space frame structure applicated in the building if it has a distance which very wide. The application is easy, so this structure usually uses at the building.

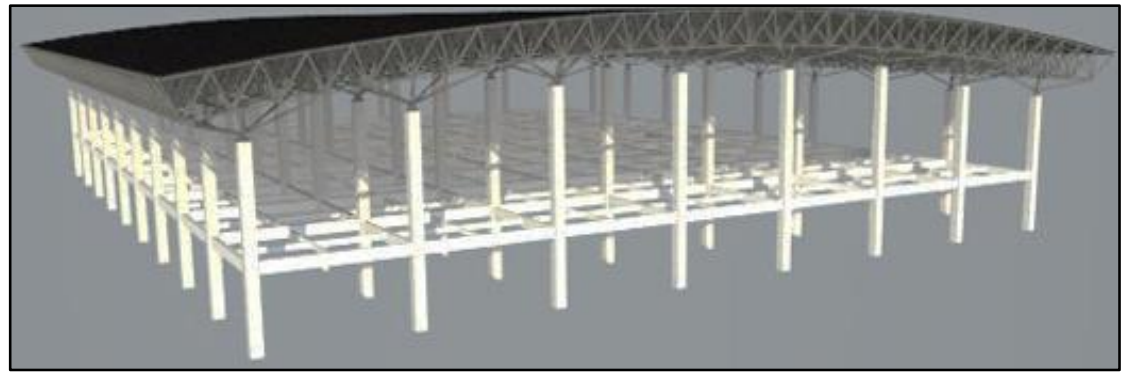

Figure 14. Building Structure

\section{Utility}

The most prominent utility system in buildings that applies tropical elements is air conditioning. The buildings function plays a role in accommodating community activities usually use mechanical air conditioning such as the use of air conditioning. It is intended so that the people inside the building feel comfortable room temperature. However, considering the concept of tropical architecture, the use of air conditioning is only used in semi-public and private spaces such as ballrooms, meeting rooms and offices. Whereas in the public area using natural air conditioning is produced through ventilation gaps.

\section{Conclusion}

The convention hall design is a means as a medium for a meeting room to facilitate activities such as the city of Medan such as meeting with climate-friendly concepts in Indonesia, which is a tropical climate. Like the use of cross ventilation concept that applies to public areas. The placement of service areas in the western part base on the theory of tropical architecture and the application of sloping roofs which enable the rainwater to flow well. Besides that, the use of wood materials for some interiors, and the application of shading on the building facade as a buffer for the sun's heat and beautifying the building facade. Plant the trees around the site 
location is also one of the solutions for this problem according to the theory of tropical architecture.

Taking into account of the rapid development of building construction in the suburbs of Medan today, this building is also expected to become one of the icons of Medan. Especially for the suburbs area of Medan, Indonesia.

\section{Acknowledgment}

This researchers have prepared this article and was partly funded by the Department of Architecture Universitas Sumatera Utara as a contribution to the city government in planning and design to maintain existing local wisdom.

\section{REFERENCES}

[1] Lawson. F, Conference, Convention, and Exhibition. New York: Architectural Press, 1981.

[2] (2017, October) Wikipedia. [Online]. https://id.wikipedia.org/wiki/Pusat_konvensi

[3] Lynch. K, The Image of The City.: MIT Press, 1960, vol. XI.

[4] Nasution. A. D, Harisdani. D.D, and Napitupulu. P. P, "The Implementation of Aerotropolis Concept on New Town Planning and Design in Mebidangro, Sumatera Utara," IOP Conference Series: Materials Science and Engineering, vol. 180, no. 1, p. 012293 , March 2017.

[5] Karyono. T.H, "Mendefinisikan Kembali Arsitektur tropis di Indonesia," Majalah Desain Arsitektur, vol. I, pp. 7-8, 2000.

[6] Talarosha. B, "Menciptakan kenyamanan thermal dalam bangunan," Jurnal Sistem Teknik Industri, vol. VI, no. 3, 2005.

[7] Karyono. T.H, Arsitektur Tropis Bentuk, Teknologi, Kenyamanan, dan Penggunaan Energi. Jakarta, Indonesia: Erlangga, 2016.

[8] Diem. A.D, "Kearifan Arsitektur Lokal Dalam Beradaptasi Terhadap Kondisi Iklim Di Daerah Tropis Lembab (Studi Kasus: Pemukiman Rumah Rakit Di Sungai Musi Palembang," Journal of Architecture and Wetland Environment Studies, vol. I, no. 1, 2012.

[9] Shirvani. H, The urban design process.: Van Nostrand Reinhold Company, 1985.

[10] T.H. Karyono, Arsitektur Tropis Bentuk, Teknologi, Kenyamanan, dan Penggunaan Energi. Jakarta, Indonesia: Erlangga, 2016. 
[11] Ching. F. D, Architecture: Form, Space, and Order.: John Wiley \& Sons, 2014.

[12] Neufert. E, Data Arsitek, 33rd ed. Jakarta, Indonesia: Erlangga, 2002, vol. 2.

[13] Neufert. E, Data Arsitek, 33rd ed. Jakarta, Indonesia: Erlangga, 2002, vol. 1.

[14] Juwana. J, Panduan Sistem Bangunan Tinggi. Jakarta, Indonesia: Erlangga, 2005. 